\title{
Dietary fish oil and digestible protein modify susceptibility to lipid peroxidation in the muscle of rainbow trout (Oncorhynchus mykiss) and sea bass (Dicentrarchus labrax)
}

\author{
M. J. Alvarez ${ }^{1}$, C. J. Lopez-Bote ${ }^{2}$, A. Diez ${ }^{1}$, G. Corraze ${ }^{3}$, J. Arzel ${ }^{4}$, J. Dias ${ }^{3}$, S. J. Kaushik ${ }^{3}$ \\ and J. M. Bautista ${ }^{1} *$ \\ ${ }^{1}$ Departamento de Bioquímica y Biología Molecular IV and \\ ${ }^{2}$ Departamento de Producción Animal, Universidad Complutense de Madrid, Facultad de Veterinaria, 28040 Madrid, Spain \\ ${ }^{3}$ Fish Nutrition Laboratory, Unité Mixte INRA-IFREMER, \\ 64310 Saint Pée-sur-Nivelle, France \\ ${ }^{4}$ Fish Nutrition Laboratory, Unité Mixte INRA-IFREMER, Centre de Brest IFREMER, 29280 Plouzané, France
}

(Received 10 June 1997 - Revised 6 March 1998 - Accepted 23 April 1998)

\begin{abstract}
The effects of dietary fish oil and digestible protein (DP) levels on muscle fatty acid composition and susceptibility to lipid peroxidation were studied in two representative fish species for human nutrition, from fresh and seawater, rainbow trout (Oncorhynchus mykiss) and European sea bass (Dicentrarchus labrax). In rainbow trout, higher concentrations of dietary fat and DP led to higher weight gain $(\mathrm{g} / \mathrm{d})(P=0 \cdot 001$ and $P=0 \cdot 043$ respectively). Additionally, an interaction effect was observed in this species, since the effect of DP was only evident when the dietary fat concentration was low $(P=0 \cdot 043)$. A similar tendency was also observed in European sea bass, although with less marked differences among nutritional treatments. Trout fed on diets with a higher concentration of dietary fat had higher concentrations of intramuscular total and neutral lipids in the dorsal muscle $(P=0 \cdot 005)$. Increased levels of dietary DP led to significantly lower concentrations of polar lipids in the dorsal muscle of both rainbow trout $(P=0.005)$ and European sea bass $(P=0.006)$. In the neutral fraction of intramuscular lipids of dorsal muscle the concentration of $n-3$ fatty acids was positively affected by the dietary fat concentration in both rainbow trout $(P=0 \cdot 04)$ and sea bass $(P=0 \cdot 001)$. Muscle homogenates from trout and sea bass fed on diets rich in fish oil showed a significantly higher susceptibility to oxidation than muscle homogenates from fish fed on low-fat diets $(P=0 \cdot 001)$. The higher DP concentration also increased susceptibility to oxidation. Moreover, in rainbow trout an interaction effect was observed where the pro-oxidant effect was of higher magnitude when the dietary concentration of both nutrients, fat and protein, was high $(P=0 \cdot 004)$.
\end{abstract}

Muscle: Lipid peroxidation: Fish nutrition

Recommended digestible energy (DE) and digestible protein (DP) contents and DP:DE ratios in diets for teleosts are very variable depending on the species. A common recommendation for DE in rainbow trout diets is in the range 15$17 \mathrm{MJ} / \mathrm{kg}$ (National Research Council, 1993). For European sea bass, although no defined recommendation has been provided, recalculation of data from the literature suggests that a similar range would be applicable (National Research Council, 1993). The current recommendations for the dietary concentration of DP are 330-420 g/kg and above $450 \mathrm{~g} / \mathrm{kg}$ for rainbow trout and European sea bass respectively (National Research Council, 1993). The higher recommended DP level in teleosts than in terrestrial species is partly due to their different metabolic abilities to use proteins for energetic purposes (Smith et al. 1978; Cho \& Kaushik, 1990). However, numerous studies have shown that an increase in DE may allow protein sparing (Kellem \& Sinnhuber, 1982; Cho \& Kaushik, 1990) and that the optimal DP:DE ratio for rainbow trout may be lowered from 22-25 to 17-19 g DP/MJ DE (Kaushik \& Médale, 1994).

There is increased interest in nutrient-dense diets for fish feeding in order to decrease metabolic losses and nitrogenous loading into the environment (Robert et al. 1993). Increased DE levels are achieved mostly by the inclusion 
of a high concentration of dietary oils, even up to $300 \mathrm{~g} / \mathrm{kg}$ (Hillestad \& Johnsen, 1994). Fish oil is a commonly used fat source in fish diets due to its high proportion of $n-3$ fatty acids, which are nutritionally essential to teleosts (Lee et $a l$. 1967; Yu \& Sinnhuber, 1979; National Research Council, 1993). Nevertheless, the inclusion of fat in fish diets must take into account its additional effect on carcass and flesh quality. Previous studies have shown that high-fat diets in fish lead to an increase in fat deposition and that there is a close correlation between dietary and muscle fatty acid compositions (Sargent et al. 1989). Some reports have indicated that $n-3$ fatty acids are particularly susceptible to lipid peroxidation (Hu et al. 1989). Lipid oxidation is of critical importance in fish quality because of the relatively short shelf-life of fish. Any modification in the feeding system should be evaluated in terms of fatty acid composition and susceptibility to oxidation. On the other hand, the source of dietary energy other than fat has been suggested to be of importance in the development of lipid oxidation (Lopez-Bote et al. 1997).

Whilst it is generally recognized that the fatty acid composition of fish muscle is closely related to the dietary fatty acid composition (Sargent et al. 1989), there is, to our knowledge, scant information on the post-harvest quality in terms of fish flesh lipid oxidation as affected by DE, and particularly DP, in farmed fish, except for studies with channel catfish (Ictalurus punctatus) grown under pond conditions (Huang et al. 1991, 1992).

The objectives of the present research were: (1) to evaluate the influence of dietary protein and fat levels on fatty acid composition of fish muscle; (2) to relate these findings to susceptibility of flesh to lipid peroxidation; and (3) to verify whether intermediary metabolism activity related to lipogenesis and deposition of fat could account for the differential susceptibility to flesh peroxidation.

\section{Materials and methods}

\section{Diets, growth trials and digestibility}

Rainbow trout (Oncorhynchus mykiss) and European sea bass (Dicentrarchus labrax) were fed on dry pelleted diets formulated with practical ingredients to contain high (HP) or low (LP) levels of crude protein and high (HF) and low (LF) levels of dietary fat (Tables 1 and 2). The experimental diets used for sea bass were formulated to contain slightly higher protein levels than those for trout, according to the National Research Council (1993) recommendations for these species. Concentrations of essential fatty acids in diets employed for both species were also above the National Research Council (1993) recommendations.

Growth trials with rainbow trout for a period of 12 weeks were conducted at the Institut National de la Recherche Agronomique (INRA) experimental fish farm in Donzacq (Landes, France) at a constant water temperature of $17 \pm 1^{\circ}$. Growth trials with sea bass were undertaken in the seawater (salinity: $35 \mathrm{~g} / \mathrm{l}$ ) facilities of IFREMER, at Centre de Brest (Plouzané, France), where the water temperature was constantly maintained at $20^{\circ}$. Juvenile rainbow trout (mean body weight $73 \mathrm{~g}$; aged up to 1 year) were distributed into groups of 100 fish each in plastic tanks (volume $4 \mathrm{~m}^{3}$ ). Triplicate groups were fed by hand twice daily to satiety. European sea bass (mean body weight $130 \mathrm{~g}$; aged $>1$ year) were distributed into groups of forty-five fish in plastic tanks $(1.5 \times 1.5 \times 1 \mathrm{~m})$ for a period of 12 weeks. Duplicate groups were fed by hand twice daily near to satiation. In both trials,

Table 1. Main ingredients, chemical composition, gross energy, digestible energy and digestible protein contents of diets for rainbow trout containing high $(H)$ or low $(L)$ levels of protein $(P)$ and fat $(F)$

\begin{tabular}{|c|c|c|c|c|}
\hline & \multicolumn{2}{|c|}{ LP } & \multicolumn{2}{|c|}{ HP } \\
\hline & LF & HF & LF & HF \\
\hline \multicolumn{5}{|l|}{ Ingredients (g/kg) } \\
\hline Fish meal (herring, crude protein $>700 \mathrm{~g} / \mathrm{kg}$ ) & 400 & 400 & 500 & 500 \\
\hline Fish protein soluble concentrate & 50 & 50 & 50 & 50 \\
\hline Fish oil & 30 & 120 & 20 & 110 \\
\hline Gelatinized maize starch & 370 & 280 & 280 & 190 \\
\hline Maize gluten & 100 & 100 & 100 & 100 \\
\hline Vitamin premix ${ }^{*}$ & 20 & 20 & 20 & 20 \\
\hline Mineral premix $\dagger$ & 10 & 10 & 10 & 10 \\
\hline Binder (sodium alginate) & 20 & 20 & 20 & 20 \\
\hline \multicolumn{5}{|l|}{ Chemical composition (g/kg DM) } \\
\hline Dry matter $(\mathrm{g} / \mathrm{kg})$ & 862 & 883 & 861 & 872 \\
\hline Protein & 388 & 379 & 460 & 449 \\
\hline Crude fat & 82 & 185 & 89 & 186 \\
\hline Ash & 90 & 88 & 104 & 104 \\
\hline Gross energy (kJ/g DM) & $20 \cdot 3$ & $22 \cdot 4$ & $20 \cdot 6$ & $22 \cdot 5$ \\
\hline Digestible energy (kJ/g DM) & $16 \cdot 4$ & $19 \cdot 8$ & $17 \cdot 6$ & $20 \cdot 2$ \\
\hline Digestible protein & 335 & 339 & 409 & 406 \\
\hline
\end{tabular}

* Provided (mg/kg diet): DL- $\alpha$-tocopheryl acetate 60 , sodium menadione bisulfate 5 , retinyl acetate 4.5 , DLcholecalciferol 0.075 , thiamin 15 , riboflavin 30 , pyridoxine 15 , cyanocobalamin 0.05 , nicotinic acid 175 , pteroylmonoglutamic acid 5 , ascorbic acid 500 , inositol 1000 , biotin $2 \cdot 5$, calcium pantothenate 50 , choline 2000.

†Provided (g/kg diet): $\mathrm{CaCO}_{3}(40 \% \mathrm{Ca}) 2 \cdot 15, \mathrm{MgO}(60 \% \mathrm{Mg}) 1 \cdot 24$, ferric citrate $0 \cdot 2, \mathrm{KI}(75 \% \mathrm{l}) 0 \cdot 4 \mathrm{mg}, \mathrm{ZnSO}_{4}$ $(36 \% \mathrm{Zn}) 0 \cdot 4, \mathrm{CuSO}_{4}(25 \% \mathrm{Cu}) 0.3, \mathrm{MnSO}_{4}(33 \% \mathrm{Mn}) 0 \cdot 3, \mathrm{Ca}_{3}\left(\mathrm{PO}_{4}\right)_{2}(20 \% \mathrm{Ca}, 18 \% \mathrm{P}) 5, \mathrm{CoSO}_{4} 0.002$, sodium selenite $(30 \% \mathrm{Se}) 0.003, \mathrm{KCl} 0.9, \mathrm{NaCl} 0.4$. 
Table 2. Main ingredients, chemical composition, gross energy, digestible energy and digestible protein contents of diets for European sea bass containing high $(H)$ or low $(L)$ levels of protein $(P)$ and fat $(F)$

\begin{tabular}{|c|c|c|c|c|}
\hline & \multicolumn{2}{|c|}{ LP } & \multicolumn{2}{|c|}{$\mathrm{HP}$} \\
\hline & LF & HF & LF & HF \\
\hline \multicolumn{5}{|l|}{ Ingredients $(\mathrm{g} / \mathrm{kg})$} \\
\hline Fish meal (herring, crude protein $>700 \mathrm{~g} / \mathrm{kg}$ ) & 360 & 360 & 460 & 460 \\
\hline Fish protein soluble concentrate & 100 & 100 & 100 & 100 \\
\hline Fish oil & 30 & 120 & 30 & 120 \\
\hline Gelatinized maize starch & 320 & 230 & 200 & 110 \\
\hline Maize gluten & 90 & 90 & 90 & 90 \\
\hline Vitamin premix ${ }^{*}$ & 20 & 20 & 20 & 20 \\
\hline Mineral premix $†$ & 10 & 10 & 10 & 10 \\
\hline Binder (guaranate) & 20 & 20 & 20 & 20 \\
\hline \multicolumn{5}{|l|}{ Chemical composition (g/kg DM) } \\
\hline Dry matter $(\mathrm{g} / \mathrm{kg})$ & 923 & 941 & 931 & 949 \\
\hline Protein & 427 & 428 & 520 & 521 \\
\hline Crude fat & 90 & 182 & 93 & 184 \\
\hline Ash & 65 & 63 & 81 & 79 \\
\hline Gross energy (kJ/g DM) & $21 \cdot 1$ & $23 \cdot 2$ & $21 \cdot 4$ & $23 \cdot 3$ \\
\hline Digestible energy (kJ/g DM) & $15 \cdot 0$ & $19 \cdot 5$ & $16 \cdot 7$ & $17 \cdot 5$ \\
\hline Digestible protein & 277 & 342 & 412 & 378 \\
\hline
\end{tabular}

* Provided (mg/kg diet): DL- $\alpha$-tocopheryl acetate 60 , sodium menadione bisulfate 5 , retinyl acetate $4 \cdot 5$, DLcholecalciferol 0.075 , thiamin 15 , riboflavin 30 , pyridioxone 15 , cyanocobalamin 0.05 , nicotinic acid 175 , pteroylmonoglutamic acid 5 , ascorbic acid 500 , inositol 1000 , biotin $2 \cdot 5$, calcium pantothenate 50 , choline 2000.

†Provided (g/kg diet): $\mathrm{CaCO}_{3}(40 \% \mathrm{Ca}) 2 \cdot 15, \mathrm{MgO}(60 \% \mathrm{Mg}) 1 \cdot 24$, ferric citrate $0 \cdot 2, \mathrm{KI}(75 \% \mathrm{l}) 0 \cdot 4 \mathrm{mg}, \mathrm{ZnSO}_{4}$ $(36 \% \mathrm{Zn}) 0.4, \mathrm{CuSO}_{4}(25 \% \mathrm{Cu}) 0.3, \mathrm{MnSO}_{4}(33 \% \mathrm{Mn}) 0.3, \mathrm{Ca}_{3}\left(\mathrm{PO}_{4}\right)_{2}(20 \% \mathrm{Ca}, 18 \% \mathrm{P}), \mathrm{CoSO}_{4} 0.002$, sodium selenite $(30 \% \mathrm{Se}) 0.003, \mathrm{KCl} 0.9, \mathrm{NaCl} 0.4$.

fish were group-weighed and counted every 3 weeks to follow growth and feed intake. To calculate DE and DP of feeds, the apparent digestibility was measured by means of an inner tracer $\left(10 \mathrm{~g} \mathrm{Cr}_{2} \mathrm{O}_{3} / \mathrm{kg}\right)$ as previously described (Gomes et al. 1993). Triplicate groups of ten fish were adapted over more than a fortnight to the diets. Faeces were collected daily for $6 \mathrm{~d}$, frozen and freeze-dried before analyses.

\section{Sample collection}

At the end of the trial, after final weighings, ten fish from each group were stunned and withdrawn to remove the dorsal muscle, which was vacuum packed, frozen in liquid $\mathrm{N}_{2}$ and subsequently stored at $-70^{\circ}$. Liver samples from six additional fish from each group were withdrawn, brought to the laboratory, treated immediately and analysed for enzyme activities within $36 \mathrm{~h}$. Proximate composition analyses of the dietary ingredients, diets and faeces were carried out following the usual laboratory procedures as previously described (Gomes et al. 1993).

\section{Lipid analyses}

Lipid oxidation studies were carried out within 1 week of slaughter, and fatty acid composition analyses within 1 month of slaughter. Polar lipids from muscle and liver samples were obtained according to the method developed by Marmer \& Maxwell (1981) and methylated by $2 \mathrm{M}$-alcoholic methanol- $\mathrm{KOH}$ in a $0.7 \mathrm{M}-\mathrm{HCl}-$ methanol solution as previously described (Lopez-Bote et al. 1997). GC identification of fatty acids was done on a 5890
Hewlett Packard gas chromatograph equipped with a split injector and flame ionization detector. A split ratio of 50:1 was used. A $30 \mathrm{~m} \times 0.32 \mathrm{~mm} \times 0.25 \mathrm{~mm}$ cross-linked polyethylene glycol capillary column was used (Hewlett Packard, Avondale, PA, USA). Analysis was performed with a temperature gradient from 170 to $245^{\circ}$. Injector and detector temperatures were maintained at $250^{\circ}$. The carrier gas was $\mathrm{He}$ at a flow rate of $3 \mathrm{ml} / \mathrm{min}$. Identification of individual fatty acids was made by comparison with known standard mixtures. Tricosanoic acid (Sigma, St Louis, MO, USA) was used as internal standard.

Susceptibility of muscle homogenates to Fe-induced lipid oxidation was determined by a modification of the method of Kornbrust \& Mavis (1980). Briefly, dorsal muscle homogenates (approximately $1 \mathrm{mg} / \mathrm{ml}$ buffer) were incubated at $37^{\circ}$ in $80 \mathrm{mM}$-Tris-maleate buffer ( $\left.\mathrm{pH} 7 \cdot 4\right)$ in the presence of $0 \cdot 2 \mathrm{M}$-ascorbic acid in a total volume of $10 \mathrm{ml}$. Portions were withdrawn, at fixed intervals, for determination of thiobarbituric acid-reactive substances (TBARS), which were expressed as nmol malonaldehyde/mg protein. Protein concentration of muscle homogenates was measured by the procedure of Bradford (1976).

\section{Enzymic analyses}

For enzyme activity determinations, liver samples were homogenized in three volumes of ice-cold buffer $(0.02 \mathrm{M}$ Tris-HCl, 0.25 M-sucrose, $2 \mathrm{mM}$-EDTA, 0.1 M-NaF, 0.5 mMphenyl methyl sulfonyl fluoride, $0 \cdot 01 \mathrm{M}-\beta$-mercaptoethanol, $\mathrm{pH} 7 \cdot 4)$. Homogenates were centrifuged at $20000 \mathrm{rev} . / \mathrm{min}$ at $4^{\circ}$ for $40 \mathrm{~min}$. The soluble protein content of liver homogenates was determined by the method of Bradford 
(1976), using bovine serum albumin as the standard. Selected lipogenic enzyme activities were assayed on supernatant fractions using spectrophotometric procedures: glucose-6-phosphate dehydrogenase (EC 1.1.1.49, G6PD) according to the method of Bautista et al. (1988) and malic enzyme (EC 1.1.1.40) according to the method of Ochoa (1955). Enzymic activity units (IU), defined as $\mu \mathrm{mol}$ substrate converted to product per min at assay temperature, were expressed either per mg hepatic soluble protein (specific activity) or per g liver tissue (wet weight).

\section{Statistical analysis}

ANOVA was used to compare differences between treatments. In addition, a repeated measurement test was used to compare differences in oxidation rate between groups during incubation. An individual fish was the experimental unit for analysis of data. In all cases statistical analyses were accomplished using software procedures contained in
Statistical Analysis Systems (1988). Data are presented as the means of each group and pooled standard deviation together with the significance levels of the main effects and interactions.

\section{Results and discussion}

Data on growth performance and dorsal muscle composition in rainbow trout and European sea bass fed on the experimental diets are presented in Tables 3 and 4 respectively. In rainbow trout, increased dietary DE level, irrespective of the DP level, led to higher weight gain $(\mathrm{g} / \mathrm{d})(P=0.001)$ and consequently to a greater final body weight $(P=0 \cdot 001)$. Growth performance showed a dietary protein effect $(P=0.043)$ in which a higher concentration of DP led to higher average daily gain. An interaction effect was detected $(P=0.003)$ in which effectiveness of higher DP level was only observed when the concentration of dietary fat was low. At high DE level, no effect of DP was found. In

Table 3. Average daily intake and gain, final weight, protein retention and intramuscular lipid content of rainbow trout fed on diets containing high $(\mathrm{H})$ or low $(\mathrm{L})$ levels of digestible protein $(\mathrm{P})$ and fat $(\mathrm{F})^{*}$

(Mean values and pooled standard deviations for 100 fish (growth studies) or ten fish (dorsal muscle))

\begin{tabular}{|c|c|c|c|c|c|c|c|c|}
\hline & \multicolumn{2}{|c|}{ LP } & \multicolumn{2}{|c|}{$\mathrm{HP}$} & Pooled SD & \multicolumn{3}{|c|}{ Probability of contrasts $†$} \\
\hline \multicolumn{9}{|l|}{ Intake } \\
\hline Digestible fat $(\mathrm{g} / \mathrm{kg} \mathrm{ABW}$ per $\mathrm{d})$ & $1 \cdot 3$ & $2 \cdot 8$ & $1 \cdot 3$ & $2 \cdot 8$ & 0.07 & NS & 0.001 & NS \\
\hline Digestible carbohydrate (g/kg ABW per d) & $5 \cdot 9$ & $4 \cdot 0$ & $4 \cdot 3$ & $2 \cdot 7$ & $0 \cdot 12$ & 0.001 & 0.001 & 0.058 \\
\hline Digestible energy (kJ/kg ABW per d) & $290 \cdot 4$ & $315 \cdot 8$ & $302 \cdot 4$ & $318 \cdot 9$ & $6 \cdot 10$ & 0.066 & 0.003 & NS \\
\hline Final body weight (g) & $256 \cdot 4$ & $306 \cdot 4$ & $276 \cdot 3$ & $302 \cdot 2$ & $24 \cdot 12$ & 0.051 & 0.001 & 0.009 \\
\hline \multicolumn{9}{|l|}{ Dorsal muscle composition (g/kg) } \\
\hline Neutral lipids & $43 \cdot 0$ & $49 \cdot 6$ & $36 \cdot 6$ & $69 \cdot 1$ & $13 \cdot 8$ & NS & 0.003 & 0.038 \\
\hline Polar lipids & $12 \cdot 4$ & $13 \cdot 5$ & $9 \cdot 3$ & $8 \cdot 4$ & $3 \cdot 0$ & 0.005 & NS & NS \\
\hline Total intramuscular fat & $55 \cdot 0$ & $63 \cdot 1$ & $45 \cdot 9$ & $77 \cdot 5$ & $13 \cdot 4$ & NS & 0.002 & 0.047 \\
\hline
\end{tabular}

ABW, average body weight.

${ }^{*}$ For details of diets and procedures, see Table 1 and pp. 282-284.

$+\mathrm{NS}, P>0.2$.

Table 4. Average daily intake and gain, final weight, protein retention and intramuscular lipid content of European sea bass fed on diets containing high $(\mathrm{H})$ or low $(\mathrm{L})$ levels of digestible protein $(\mathrm{P})$ and fat $(\mathrm{F})^{*}$

(Mean values and pooled standard deviations for forty-five fish (growth studies) or ten fish (dorsal muscle))

\begin{tabular}{|c|c|c|c|c|c|c|c|c|}
\hline & \multicolumn{2}{|c|}{ LP } & \multicolumn{2}{|c|}{ HP } & \multirow[b]{2}{*}{ Pooled SD } & \multicolumn{3}{|c|}{ Probability of contrasts $\dagger$} \\
\hline & LF & $\mathrm{HF}$ & LF & $\mathrm{HF}$ & & Protein & Fat & Interaction \\
\hline $\begin{array}{l}\text { Intake } \\
\text { Digestible protein (g/kg ABW per d) } \\
\text { Digestible fat (g/kg ABW per d) } \\
\text { Digestible carbohydrate (g/kg ABW per d) } \\
\text { Digestible energy (kJ/kg ABW per d) }\end{array}$ & $\begin{array}{l}3 \cdot 43 \\
0 \cdot 16 \\
0 \cdot 73 \\
2 \cdot 95\end{array}$ & $\begin{array}{l}3 \cdot 08 \\
0 \cdot 15 \\
1 \cdot 22 \\
2 \cdot 01\end{array}$ & $\begin{array}{l}4 \cdot 40 \\
0 \cdot 17 \\
0 \cdot 68 \\
2 \cdot 17\end{array}$ & $\begin{array}{l}3 \cdot 93 \\
0 \cdot 16 \\
1.31 \\
1.30\end{array}$ & $\begin{array}{l}0 \cdot 157 \\
0 \cdot 007 \\
0 \cdot 049 \\
0 \cdot 110\end{array}$ & $\begin{array}{l}0.001 \\
\text { NS } \\
\text { NS } \\
0.001\end{array}$ & $\begin{array}{l}0.022 \\
N S \\
0 \cdot 001 \\
0.001\end{array}$ & $\begin{array}{l}\text { NS } \\
\text { NS } \\
\text { NS } \\
\text { NS }\end{array}$ \\
\hline Average daily gain (g/d) & 0.56 & 0.60 & 0.59 & 0.65 & 0.039 & NS & NS & NS \\
\hline Final body weight (g) & 210 & 218 & 217 & 229 & $8 \cdot 172$ & NS & NS & NS \\
\hline $\begin{array}{l}\text { Dorsal muscle composition }(\mathrm{g} / \mathrm{kg} \text { ) } \\
\text { Neutral lipids } \\
\text { Polar lipids } \\
\text { Total intramuscular fat }\end{array}$ & $\begin{array}{l}39 \cdot 3 \\
22 \cdot 1 \\
61 \cdot 4\end{array}$ & $\begin{array}{l}47 \cdot 4 \\
19 \cdot 0 \\
66 \cdot 4\end{array}$ & $\begin{array}{l}29 \cdot 0 \\
13 \cdot 2 \\
42 \cdot 2\end{array}$ & $\begin{array}{l}32 \cdot 5 \\
12 \cdot 9 \\
45 \cdot 4\end{array}$ & $\begin{array}{r}13.82 \\
5.26 \\
15.35\end{array}$ & $\begin{array}{c}N S \\
0.006 \\
0.010\end{array}$ & $\begin{array}{l}\text { NS } \\
\text { NS } \\
\text { NS }\end{array}$ & $\begin{array}{l}\text { NS } \\
\text { NS } \\
\text { NS }\end{array}$ \\
\hline
\end{tabular}

ABW, average body weight.

${ }^{*}$ For details of diets and procedures, see Table 2 and pp. 282-284.

$+\mathrm{NS}, P>0.2$. 
view of these results it is apparent that protein economy can be efficiently achieved by decreasing DP levels when high levels of dietary fat are included. The protein-sparing effect of fat observed with 378.8 as compared with $449.4 \mathrm{~g}$ crude protein $/ \mathrm{kg}$ feed is substantiated in other reports (Kellem \& Sinnhuber, 1982; Legrow \& Beamish, 1986). Recently it has been reported that the growth of Atlantic salmon (Salmo salar) can be optimal under practical conditions with only $390 \mathrm{~g}$ protein/ $\mathrm{kg}$ diet corresponding to $17 \cdot 6 \mathrm{~g}$ crude protein/ MJ gross energy (Hillestad \& Johnsen, 1994). Rainbow trout fed on the LP-HF diet had a DP:DE ratio of $17 \mathrm{~g} / \mathrm{MJ}$, which is lower than those usually recommended (National Research Council, 1993). Moreover, results from growth studies pointed out that rainbow trout fed on diets with the higher concentrations of DP and DE received a daily income of protein above the requirements for optimal growth and feed utilization. On the other hand, daily gain was positively affected by a higher level of protein when the dietary DE concentration was low (group LP-LF $v$. HP-LF). In this case, a DP:DE ratio of $23 \mathrm{~g} / \mathrm{MJ}$ would appear to be more favourable than 20 .

Equivalent dietary treatments in European sea bass had similar effects, although with less marked differences among groups (Table 4). No significant effect was observed on average daily gain and final body weight. A reduction in the amount of dietary protein did not negatively affect growth rate and muscle composition, thus, it may be of practical interest for both economical and environmental considerations.

Dorsal muscle from trout fed on diets with a high concentration of dietary fat had increased concentrations of intramuscular total lipids $(P=0.002)$ and neutral lipids $(P=0.003)$ (Table 3). Moreover, an interaction effect was detected in which the effect of dietary fat on increased muscle neutral lipid content was of higher magnitude when the diet had a high concentration of DP $(P=0.038$; Table 3). This fact suggests that an excess of dietary energy was available in the groups fed on high levels of both DP and DE, which consequently led to a higher lipid accumulation in the dorsal muscle (group HP-HF). In
European sea bass no significant effect of dietary fat or interaction with respect to the total and neutral intramuscular fat content in the dorsal muscle was detected, although a similar trend and tendency to that observed in rainbow trout was observed (see Table 4).

We found a significantly lower concentration of polar lipids in the dorsal muscle of both rainbow trout $(P=0.005$; Table 3) and European sea bass ( $P=0.006$; Table 4$)$. The phospholipid fraction has been considered to be a rather stable lipid fraction, as it supports the membrane structures of the cells (Farkas \& Csengeri, 1976). However, several reports have demonstrated that fish are able to utilize a proportion of the phospholipid fraction under some specific physiological conditions, such as starvation or gonad development (Shewfelt, 1981; Ando et al. 1985). It has been discussed whether this mobilization is done selectively by specific fatty acids or not, and its possible metabolic and flesh quality consequences have been considered (Ando et al. 1985; Takama et al. 1985; Ingemansson et al. 1995). Phospholipid hydrolysis in fish tissues is considered to be a critical aspect in relation to quality deterioration during storage (Bosund \& Ganrot, 1969; Ingemansson et al. 1995). The effect of dietary protein on the concentration of muscle phospholipid has not previously been reported and requires further research.

The fatty acid classes of neutral and polar lipids from the dorsal muscle of rainbow trout and European sea bass are shown in Tables 5 and 6 respectively. In the neutral fraction of intramuscular lipids the concentration of $n-3$ fatty acids was positively affected by the dietary fat content both in trout $(P=0 \cdot 04)$ and in sea bass $(P=0 \cdot 001)$. Additionally, an effect of dietary fat was observed on the unsaturation index (average number of double bonds per fatty acid residue) of neutral lipids in which higher dietary fat led to higher unsaturation index in trout $(P=0.065)$ and sea bass $(P=0.002)$ (Tables 5 and 6$)$. In trout, in the neutral lipid fraction it was observed that a high concentration of DP significantly reduced the unsaturation index, and levels of $n-3$ and $n-6$ polyunsaturated fatty acids $(P=0 \cdot 037$, $P=0.079$ and $P=0.007$ respectively), and increased the

Table 5. Fatty acid classes composition ( $\mathrm{g} / 100 \mathrm{~g}$ total fatty acids) of the neutral and polar fractions of intramuscular lipids of rainbow trout fed on diets containing high $(H)$ or low $(L)$ levels of digestible protein $(P)$ and fat $(F)^{*}$

(Mean values and pooled standard deviation for ten fish)

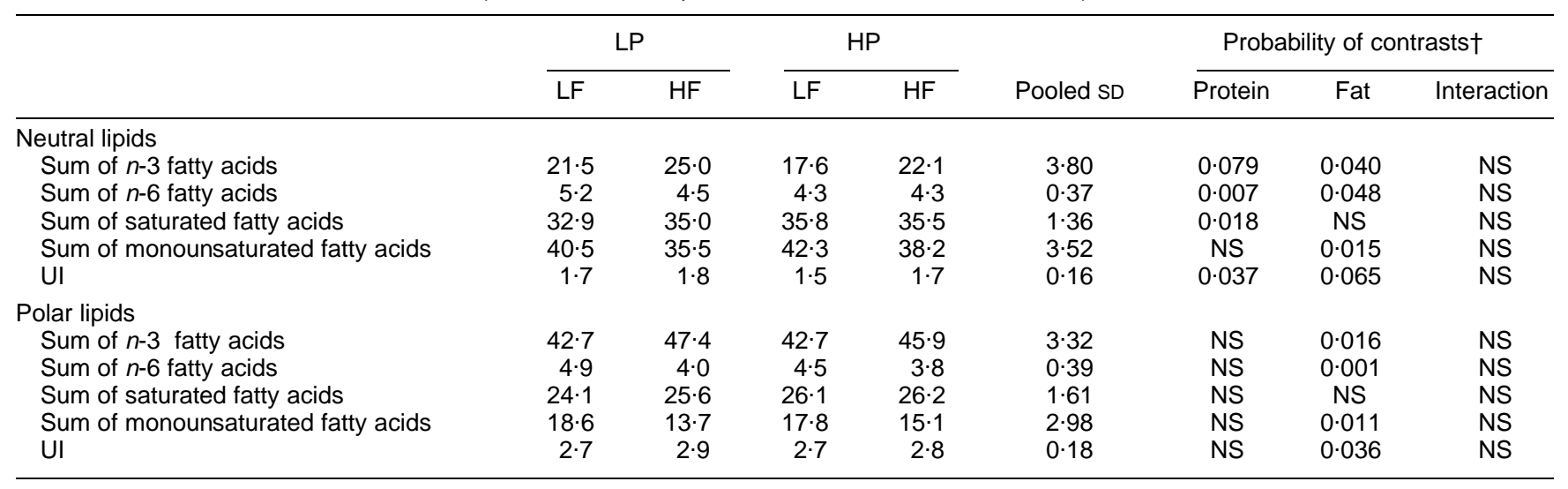

UI, unsaturation index (average number of double bonds per fatty acid residue).

* For details of diets and procedures, see Table 1 and pp. 282-284.

† NS, $P>0.2$. 
Table 6. Fatty acid classes composition ( $\mathrm{g} / 100 \mathrm{~g}$ total fatty acids) of the neutral and polar fractions of intramuscular lipids of European sea bass fed on diets containing high $(H)$ or low $(L)$ levels of digestible protein $(P)$ and fat $(F)^{*}$

(Mean values and pooled standard deviation for ten fish)

\begin{tabular}{|c|c|c|c|c|c|c|c|c|}
\hline & \multicolumn{2}{|c|}{ LP } & \multicolumn{2}{|c|}{$\mathrm{HP}$} & Pooled SD & \multicolumn{3}{|c|}{ Probability of contrasts $\dagger$} \\
\hline \multicolumn{9}{|l|}{ Neutral lipids } \\
\hline Sum of $n-6$ fatty acids & $8 \cdot 8$ & $7 \cdot 7$ & $8 \cdot 0$ & $7 \cdot 5$ & 1.90 & NS & NS & NS \\
\hline Sum of saturated fatty acids & $31 \cdot 6$ & $31 \cdot 6$ & $33 \cdot 4$ & $33 \cdot 3$ & 1.46 & 0.018 & NS & NS \\
\hline Sum of monounsaturated fatty acids & $41 \cdot 8$ & $37 \cdot 4$ & $41 \cdot 6$ & $37 \cdot 2$ & 1.58 & NS & 0.001 & NS \\
\hline Sum of $n-3$ fatty acids & $43 \cdot 6$ & $44 \cdot 5$ & $42 \cdot 2$ & $42 \cdot 7$ & $2 \cdot 07$ & NS & NS & NS \\
\hline Sum of $n-6$ fatty acids & $5 \cdot 3$ & 4.9 & $5 \cdot 1$ & $5 \cdot 1$ & 0.30 & NS & NS & NS \\
\hline Sum of saturated fatty acids & $27 \cdot 4$ & $27 \cdot 0$ & $28 \cdot 1$ & $29 \cdot 7$ & $1 \cdot 23$ & 0.014 & NS & NS \\
\hline Sum of monounsaturated fatty acids & $22 \cdot 3$ & $22 \cdot 2$ & $23 \cdot 4$ & $21 \cdot 2$ & 1.97 & NS & NS & NS \\
\hline UI & $2 \cdot 8$ & $2 \cdot 8$ & $2 \cdot 7$ & $2 \cdot \overline{7}$ & $0 \cdot 11$ & $0 \cdot 131$ & NS & NS \\
\hline
\end{tabular}

$\mathrm{UI}$, unsaturation index (average number of double bonds per fatty acid residue).

${ }^{*}$ For details of diets and procedures, see Table 2 and pp. 282-284.

†NS, $P>0.2$.

level of saturated fatty acids $(P=0 \cdot 018)$ (Table 5). Additionally, a higher concentration of monounsaturated fatty acids was observed, although this tendency was not statistically sustained (Table 5). A similar trend was also observed in the fatty acid classes of the neutral lipids from European sea bass (Table 6), but the only significant effect of dietary protein was the production of a higher proportion of saturated fatty acids in the neutral lipids $(P=0 \cdot 018)$. The final end-products of lipid synthesis in animals are saturated fatty acids (Enser, 1984). Also in this case, our results indicate that rainbow trout and European sea bass fed on diets with high DP and DE levels received a daily income of protein above the physiological needs and consequently a part of it was used for energy purposes, thus producing higher synthesis (and accumulation) of non-essential fatty acids. These results are in agreement with the observation, in trout, that high levels of dietary protein decrease the concentration of $n-3$ fatty acids in neutral lipids and increase the concentrations of monounsaturated and saturated fatty acids (Kim et al. 1989).

On the other hand, the increase in dietary fat in the form of fish oil produced a higher concentration of $n$-3 fatty acids $(P=0 \cdot 16)$ and higher unsaturation index $(P=0 \cdot 036)$ in the polar lipids of rainbow trout. The same pattern was also observed in polar lipids of sea bass (Table 6). Although this trend was also similar to that observed in the neutral lipids, we did not detect any effect of DP on the fatty acid composition of polar lipids (except for the concentration of saturated fatty acids in sea bass). Interaction between dietary fat and DP effects on fatty acid composition in neutral and polar lipids was not observed in any case.

In order to investigate changes in the metabolic pathway leading to fatty acid biosynthesis, the activity of G6PD was assessed. G6PD is a regulatory and branching enzyme producing reducing equivalents for fatty acid biosynthesis and recycling of pentoses for energy metabolism (Bautista \& Luzzatto, 1997). As seen in Table 7, G6PD activity decreased by about $50 \%$ in both rainbow trout and sea bass when the dietary fat content increased from 80 to $180 \mathrm{~g} /$ $\mathrm{kg}$ at any DP level $(P=0 \cdot 01)$. This fact indicates that low dietary fat stimulates NADPH consumption thereby generating NADP and activating the pentose phosphate pathway. Several studies have shown an effect of the level of dietary lipids on G6PD activity but, invariably, this has been in cases where the level of dietary carbohydrate is low. On the other hand, an indirect effect of carbohydrates on G6PD activity has been shown in several fish species (Hilton \& Atkinson, 1982). Increased amounts of dietary fat directly inhibit fatty acid synthesis as indicated by the parallel fall in the activity of fatty acid synthase (results not shown) and in the consumption of NADPH. Thus, the fat content of the diet has a high capacity to regulate the generation of reducing equivalents through G6PD. Regarding the effect of protein in the

Table 7. Glucose-6-phosphate dehydrogenase (G6PD) and malic enzyme (ME) activities (IU/g liver) in the liver of rainbow trout and European sea bass fed on diets containing high $(H)$ or low $(L)$ levels of digestible protein $(P)$ and fat $(F)^{*}$

(Mean values and pooled standard deviation for six fish)

\begin{tabular}{|c|c|c|c|c|c|c|c|c|}
\hline & \multicolumn{2}{|c|}{ LP } & \multicolumn{2}{|c|}{$\mathrm{HP}$} & \multirow[b]{2}{*}{ Pooled SD } & \multicolumn{3}{|c|}{ Probability of contrasts $\dagger$} \\
\hline & LF & $\mathrm{HF}$ & LF & $\mathrm{HF}$ & & Protein & Fat & Interaction \\
\hline $\begin{array}{l}\text { Rainbow trout } \\
\text { G6PD } \\
\mathrm{ME}\end{array}$ & $\begin{array}{r}57.33 \\
0.17\end{array}$ & $\begin{array}{r}20 \cdot 79 \\
0.18\end{array}$ & $\begin{array}{r}46.18 \\
0.26\end{array}$ & $\begin{array}{r}17.56 \\
0.15\end{array}$ & $\begin{array}{r}10.911 \\
0.058\end{array}$ & $\begin{array}{c}0.046 \\
\text { NS }\end{array}$ & $\begin{array}{l}0.001 \\
0.022\end{array}$ & $\begin{array}{c}\text { NS } \\
0.016\end{array}$ \\
\hline $\begin{array}{l}\text { European sea bass } \\
\text { G6PD } \\
\text { ME }\end{array}$ & $\begin{array}{r}20.57 \\
3.06\end{array}$ & $\begin{array}{r}14.54 \\
2.16\end{array}$ & $\begin{array}{r}22.47 \\
0.74\end{array}$ & $\begin{array}{r}10.56 \\
1.01\end{array}$ & $\begin{array}{l}2.753 \\
0.449\end{array}$ & $\begin{array}{l}0.087 \\
0.001\end{array}$ & $\begin{array}{l}0.001 \\
0.118\end{array}$ & $\begin{array}{l}0.005 \\
0.006\end{array}$ \\
\hline
\end{tabular}

* For details of diets and procedures, see Tables 1 and 2 and pp. 282-284.

†NS, $P>0.2$. 
Table 8. Iron-induced lipid peroxidation ( $\mathrm{nmol}$ malonaldehyde/mg protein) in dorsal muscle homogenates incubated at $37^{\circ}$ for up to $240 \mathrm{~min}$ from rainbow trout fed on diets containing high $(H)$ or low $(L)$ levels of digestible protein $(P)$ and fat $(F)^{*}$

(Mean values and pooled standard deviation for ten fish)

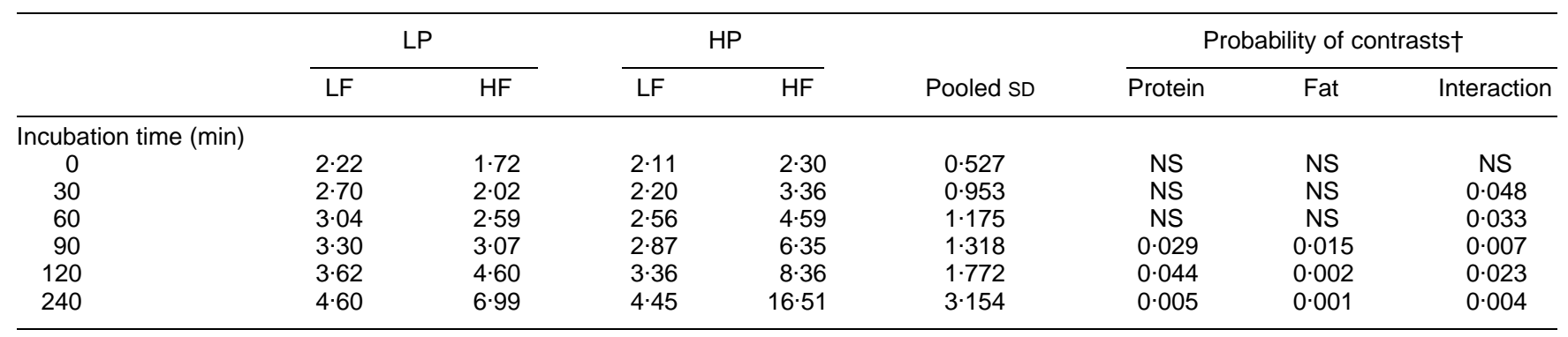

${ }^{*}$ For details of diets and procedures, see Table 1 and pp. 282-284.

†NS, $P>0.2$.

diet, in trout we observed a net decrease in the production of $\mathrm{NADPH}$ at high protein concentrations at any amount of dietary fat $(P=0 \cdot 046)$. In sea bass this effect was only observed at a high content of protein when it was accompanied by a high dietary fat content. Nevertheless, the higher activity of malic enzyme in sea bass than in trout (Table 7) and, therefore, the higher cytoplasmic NADPH production through this enzyme compensated for the difference in G6PD activity and, consequently, the net production of NADPH in sea bass was always higher at lower dietary protein at any fat concentration, equivalent to the situation observed in trout. These results indicate that part of the dietary protein supply is used for lipogenesis. Hence, increased amounts of protein favour a higher lipogenesis rate and, therefore, an increased proportion of saturated fat compared with the higher deposition of polyunsaturated fatty acids from fat in the diets with a lower protein content.

Differences in fatty acid composition among experimental groups were small in all cases when compared with reports in which the effect of dietary fat on fatty acid composition was studied (Casteldine \& Buckley, 1980). This may be due to the relatively high proportion of dietary ingredients (other than fish oil) derived from fish, which provide a fat source of similar composition to that of fish oil.

The effect of experimental diets on the susceptibility of rainbow trout and European sea bass dorsal muscle to oxidation, as assessed by induced peroxidation, was subsequently investigated (Tables 8 and 9 respectively for each species). A significant effect due to fat inclusion in the diet was seen in both species. Muscle homogenates from fish fed on HF diets showed significantly higher TBARS, after 240 min incubation, than muscle homogenates from fish fed on diets with a low fat content $(P=0 \cdot 001)$ (see Tables 8 and 9).

As expected, the higher susceptibility to oxidation occurred in muscle of fish fed on diets containing higher concentrations of fat, since the dietary fat source was fish oil, which has a high concentration of highly unsaturated fatty acids (particularly $n-3$ fatty acids) (Austreng \& Krogdahl, 1987). Moreover, a direct relationship has been observed between long-chain $n$-3 fatty acid concentration and lipid oxidation of muscle homogenates (Lopez-Bote et al. 1997). Hu et al. (1989) compared the susceptibility of tissue from rats fed on diets high in $n-3$ or $n-6$ polyunsaturated fatty acids to in vitro lipid peroxidation and observed a higher level of TBARS in tissues from those animals receiving higher levels of $n-3$ fatty acids. This is consistent with other reports suggesting an enhanced susceptibility to lipid peroxidation of $n-3$ fatty acids, either as pure lipid or in tissues of rats fed on fish oil instead of maize oil (Hammer \& Wills, 1978). Susceptibility of $n-3$ fatty acids to oxidation seems to be particularly localized in highly unsaturated fatty acid residues. Eichenberger et al. (1982) reported that lipid peroxidation in isolated membranes, as measured by TBARS, occurred mainly in $n-3$ fatty acids containing five or six double bonds. In vivo experiments showed that urinary TBARS started to increase as soon as long-chain $n$-3 fatty acids were substantially incorporated into body lipid at the expense of $n$ - 6 fatty acids (De Schrijver et al. 1992). This result fits with the correlation found between tissue incorporation of long-chain $n-3$ fatty acids and urinary TBARS (L'Abbé et al. 1991).

Table 9. Iron-induced lipid peroxidation (nmol malonaldehyde/mg protein) in dorsal muscle homogenates incubated at $37^{\circ}$ for up to $240 \mathrm{~min}$ from European sea bass fed on diets containing high $(H)$ or low $(L)$ levels of digestible protein $(P)$ and fat $(F)^{*}$

(Mean values and pooled standard deviation for ten fish)

\begin{tabular}{|c|c|c|c|c|c|c|c|c|}
\hline & \multicolumn{2}{|c|}{ LP } & \multicolumn{2}{|c|}{$\mathrm{HP}$} & Pooled SD & \multicolumn{3}{|c|}{ Probability of contrasts $\dagger$} \\
\hline \multicolumn{9}{|c|}{ Incubation time (min) } \\
\hline 30 & 0.19 & 0.29 & 0.21 & 0.49 & $0 \cdot 127$ & 0.068 & 0.004 & NS \\
\hline 60 & 0.27 & 0.52 & 0.30 & $0 \cdot 76$ & $0 \cdot 133$ & 0.039 & 0.001 & NS \\
\hline 120 & 0.37 & 0.78 & 0.44 & 1.01 & $0 \cdot 179$ & 0.078 & 0.001 & NS \\
\hline 240 & 0.51 & 1.03 & 0.66 & $1 \cdot 24$ & 0.239 & $0 \cdot 114$ & 0.001 & NS \\
\hline
\end{tabular}

* For details of diets and procedures, see Table 2 and pp. 282-284.

†NS, $P>0.2$. 
We observed a significantly higher TBARS concentration in muscle homogenates from rainbow trout fed on diets containing a higher concentration of DP $(P=0 \cdot 05$; Table 8). A similar effect was also observed in European sea bass homogenates, but the pro-oxidant effect of higher levels of dietary protein was only evident between 30 and $60 \mathrm{~min}$ of incubation (Table 9). The pro-oxidant effect of a high concentration of dietary protein was unexpected and needs further investigation. According to fatty acid composition and overall unsaturation (Tables 5 and 6), a high concentration of DP should be expected to affect lipid oxidation negatively. Several factors may be involved in this unexpected higher susceptibility to oxidation. The rate of lipid oxidation in muscle systems, other than overall unsaturation of fatty acids, depends on a number of factors including the presence of free fatty acids, concentration of pro-oxidants (Fe and other pro-oxidants, enzyme mediators, etc.) (Tichivangana \& Morrissey, 1985) and the presence of antioxidants (Frigg et al. 1990). As described earlier, we found significant effects of dietary treatments on the concentration of muscle phospholipids (Tables 3 and 4), liver enzyme activities (Table 7) and intramuscular total lipid concentration (Tables 3 and 4), which partially explain the differences in the susceptibility to oxidation among experimental groups. The lower concentration of phospholipids in muscles from fish fed on higher levels of protein suggest higher lipid hydrolysis. The possible action of phospholipase hydrolysis pre- and post-mortem may produce a net decrease in the concentration of membrane phospholipids and a concomitant rise in the content of highly unsaturated free fatty acids which have been shown to produce a negative effect on lipid stability (Labuza, 1971; Shewfelt, 1981). The effect of dietary protein on the susceptibility to lipid oxidation has not been previously reported either in rainbow trout or in European sea bass, and understanding its principles will require further research.

Additionally, G6PD is the main cytoplasmic enzyme generating reducing power in the form of NADPH, which is, in turn, linked to intracellular antioxidant capacity through a cascade of other enzyme activities (Barroso et al. 1994; Bautista \& Luzzatto, 1997). Data on G6PD activity, i.e. production of reducing equivalents, correlate with the susceptibility to peroxidation: lower G6PD activity is present in those animals with higher susceptibility to oxidation. Since no correlation was found in total fatty acids and membrane lipids which could account for the higher susceptibility to oxidation in animals fed on diets enriched in protein, the data on G6PD activity could indicate the involvement of pro-antioxidant environments linked to enzyme activities and the availability of metabolic NADPH.

Moreover, an interaction effect of the dietary levels of protein and fat was observed in trout, in which the pro-oxidant effect was of higher magnitude when the dietary concentration of both nutrients was high $(P=0 \cdot 04$; Table 8$)$. A possible explanation might be the differences in the total amount of intramuscular fat between the treatments (Table 3) and/or different concentrations of other compositional factors, such as $\mathrm{Fe}$, which might have had different concentrations in the diet due to the inclusion of two levels of fish meal (Tables 1 and 2) and, therefore have acted as pro-oxidants during storage of fish flesh (Han \& Liston, 1988).

Inclusion of fish oils and high levels of protein in rainbow trout and sea bass diets increases the susceptibility of fish flesh to oxidative deterioration. This may be explained in part by differences in intramuscular fat content, fatty acid composition and the activities of some enzymes of intermediary metabolism. In nutrient-dense diets for rainbow trout and European sea bass, DP concentration can be reduced with a concomitant beneficial effect on flesh lipid oxidation and environmental nitrogenous loading and without negative effects on growth rate and muscle composition.

\section{Acknowledgements}

This research was supported by European Union projects AIR-CT93-0801 (Fat deposition in farmed rainbow trout and European sea bass) and AIR-CT94-1577 (Dietary treatment and oxidative stability of muscle and meat products); and by Spanish CICYT grant no. AGF95-1341. Thanks are also due to Mrs L. Larroquet, Mrs S. PerezBenavente and $\mathrm{Mr} \mathrm{M}$. Marin for their most efficient technical assistance.

\section{References}

Ando S, Hatano M \& Zama K (1985) Deterioration of chum salmon (Oncorhynchus keta) muscle during spawning migration. I. Changes in proximate composition of chum salmon muscle during spawning migration. Comparative Biochemistry and Physiology 80B, 303-307.

Austreng E \& Krogdahl A (1987) Food quality of cultured salmonids can be influenced. Feedstuffs 59, 12-14.

Barroso JB, Garcia-Salguero L, Peragon J, Higuera M \& Lupiañez JA (1994) The influence of dietary protein on the kinetics of NADPH production systems in various tissues of rainbow trout (Oncorhynchus mykiss). Aquaculture 124, 47-59.

Bautisa JM, Garrido-Pertierra A \& Soler G (1988) Glucose-6phosphate dehydrogenase from Dicentrarchus labrax liver: kinetic mechanism and kinetic of NADPH inhibition. Biochimica et Biophysica Acta 967, 354-363.

Bautista JM \& Luzzatto L (1997) Glucose-6-phosphate dehydrogenase. In Protein Dysfunction in Human Genetic Disease, pp. 33-56 [DM Swallow and YH Edwards, editors]. Oxford: BIOS Scientific Publishers.

Bosund I \& Ganrot E (1969) Lipid hydrolysis in frozen baltic herring. Journal of Food Science 34, 13-18.

Bradford M (1976) A rapid and sensitive method for the quantitation of microgram quantities of protein utilizing the principledye binding. Analytical Biochemistry 72, 248-254.

Castledine AJ \& Buckley JT (1980) Distribution and mobility of $\omega 3$ fatty acids in rainbow trout fed varying levels and types of dietary lipid. Journal of Nutrition 110, 675-685.

Cho CY \& Kaushik SJ (1990) Nutritional energetics in fish: energy and protein utilization in rainbow trout (Salmo gairdneri). World Review of Nutrition and Dietetics 61, 132-172.

De Schrijver R, Vermeulen D \& Daems V (1992) Dose-response relationships between dietary $(n-3)$ fatty acids and plasma tissue lipids, steroids excretion and urinary malonaldehyde in rats. Journal of Nutrition 122, 1979-1987.

Eichenberger K, Bohni P, Winterhalter KH, Kawato $\mathrm{S}$ \& Richter C (1982) Microsomal lipid peroxidation causes an increase in the order of membrane lipid domain. FEBS Letters 142, 59-62.

Enser M (1984) The chemistry, biochemistry and nutritional importance of animal fats. In Fats in Animal Nutrition, pp. 23 54 [J Wiseman, editor]. London: Butterworths. 
Farkas T \& Csengeri I (1976) Biosynthesis of fatty acids by the carp, Cyprinus carpio, in relation to environmental temperature. Lipids 11, 401-407.

Frigg M, Prabuck AL \& Ruhdel EU (1990) Effect of dietary vitamin E levels on oxidative stability of trout fillets. Aquaculture 84, 145-158.

Gomes EF, Coraze G \& Kaushik S (1993) Effects of dietary incorporation of a coextruded plant protein (rapeseed and peas) on growth, nutrient utilization and muscle fatty-acid composition of rainbow-trout. Aquaculture 113, 339-353.

Hammer CT \& Wills ED (1978) The role of lipid components of the diet in the regulation of the fatty acid composition of the rat liver endoplasmic reticulum and lipid peroxidation. Biochemical Journal 174, 585-593.

Han TJ \& Liston J (1988) Correlation between lipid-peroxidation and phospholipid hydrolysis in frozen fish muscle. Journal of Food Science 53, 1917.

Hillestad M \& Johnsen F (1994) High-energy low-protein diets for atlantic salmon-effects on growth, nutrient retention and slaughter quality. Aquaculture 124, 109-116.

Hilton JW \& Atkinson JI (1982) Response of rainbow trout, Salmo gairdneri, to increasing levels of available carbohydrate in practical trout diet. British Journal of Nutrition 47, 597-607.

Hu ML, Frankel EN, Leibovitz BE \& Tappel AL (1989) Effect of dietary lipid and vitamin $\mathrm{E}$ on in vitro lipid peroxidation in rat liver and kidney homogenates. Journal of Nutrition 119, 1574-1582.

Huang YW, Eitenmiller RR, Lillard DA \& Koehler PE (1991) Storage quality of iced channel catfish fed different protein levels. Journal of Food Quality 14, 345-354.

Huang YW, Lillard DA, Koehler PE \& Eitenmiller RR (1992) Chemical changes and sensory evaluation of channel catfish as affected by diet, packaging method and frozen storage. Journal of Food Quality 15, 129-138.

Ingemansson T, Kaufmann P \& Ekstrand B (1995) Multivariate evaluation of lipid hydrolysis and oxidation data from light and dark muscle of frozen stored rainbow trout (Oncorhynchus mykiss). Journal of Agricultural and Food Chemistry 43, 2046-2052.

Kaushik SJ \& Medale F (1994) Energy-requirements, utilization and dietary supply to salmonids. Aquaculture 124, 81-97.

Kellem RO \& Sinnhuber RO (1982) Performance of rainbow-trout fed gelatin-bound diets of fish-protein concentrate of casein containing 25 to 45 percent herring oil. Progressive Fishculturist 44, 131-134.

Kim JD, Kaushik SJ \& Pascaud M (1989) Effects of dietary-lipid to protein ratios on the fatty-acid composition of muscle lipids in rainbow-trout. Nutrition Reports International 40, 9-16.

Kornbrust DJ \& Mavis RD (1980) Relative susceptibility of microsomes from lung, heart, liver, kidney, brain and testes to lipid peroxidation: correlation with vitamin E content. Lipids $\mathbf{1 5}$, $315-322$.
L'Abbé MR, Trick KD \& Beare-Rogers JL (1991) Dietary (n-3) fatty acids affect rat heart, liver and aorta protective enzyme activities and lipid peroxidation. Journal of Nutrition 121, 1331-1340.

Labuza TP (1971) Kinetics of lipid oxidation in foods. CRC Critical Review of Food Technology 2, 355-405.

Lee DJ, Roem JN, Yu TC \& Sinnhuber RO (1967) Effect of $\omega 3$ fatty acids on the growth of rainbow trout, Salmo gairdneri. Journal of Nutrition 92, 93-98

Legrow SM \& Beamish FWH (1986) Influence of dietary-protein and lipid on apparent heat increment of rainbow-trout, Salmo gairdneri. Canadian Journal of Fisheries and Aquatic Sciences 43, 19-25.

Lopez-Bote CJ, Rey AJ, Sanz M, Gray IJ \& Buckley JD (1997) Dietary vegetable oils and alpha-tocopherol reduce lipid oxidation in rabbit muscle. Journal of Nutrition 127, 1176-1182.

Marmer WN \& Maxwell RJ (1981) Dry column method for the quantitative extraction and simultaneous class separation of lipids from muscle tissue. Lipids 16, 365-371.

National Research Council (1993) Nutrient Requirement of Fish. Washington, DC: National Academy of Sciences.

Ochoa S (1955) Malic enzyme. In Methods in Enzymology, vol. 1, pp. 739-753 [SP Colowicks and NO Kaplan, editors]. New York, NY: Academic Press Inc.

Robert N, Le Govvello R, Mauviot JC, Arroyo F, Aquirre P \& Kasuhik SJ (1993) Use of extruded diets in intensive trout culture: effect of protein to energy ratios on growth, nutrient utilization and on flesh and water quality. In Fish Nutrition in Practice. Les Colloques IRNA, vol. 61, pp. 497-500 [SJ Kaushik and P Luquet, editors]. Versailles Cedex: INRA.

Sargent J, Henderson RJ \& Tocher DR (1989) The lipids. In Fish Nutrition, pp. 153-218 [JE Halver, editor]. New York, NY: Academic Press Inc.

Statistical Analysis Systems (1988) SAS User's Guide: Statistics, version 6.04. Cary, NC: SAS Institute Inc.

Shewfelt RL (1981) Fish muscle lipolysis - a review. Journal of Food Biochemistry 5, 79-100.

Smith RR, Rumsey GL \& Scott ML (1978) Heat increment associated with dietary protein, fat and carbohydrate and complete diets in salmonids: comparative energetic efficiency. Journal of Nutrition 108, 1025-1032.

Takama K, Love RM \& Smith GL (1985) Selectivity in mobilisation of stored fatty acids by maturing cod, Gadus morhua L. Comparative Biochemistry and Physiology 80B, 713-718.

Tichivangana JZ \& Morrissey PA (1985) Metmyoglobin and inorganic metals as pro-oxidants in raw and cooked muscle systems. Meat Science 15, 107-116.

Yu TC \& Sinnhuber RO (1979) Effect of dietary $\omega 3$ and $\omega 6$ fatty acids on growth and fed conversion efficiency of coho salmon (Oncorhynchus kisutch). Aquaculture 16, 31-38. 